csinálni, hanem a rá háruló vagy önként vállalt feladatokat minél jobban teljesíteni. Kiváló, igaz ember volt, magas életkora feltehetőleg ezeknek is köszönhető.

A Nyelvtudományi Intézet Benczúr utcai épületében, a Szótári Osztályon is volt szobája, ahova még a kilencvenhez közeledve is viszonylag rendszeresen bejárt - mindig gyalog sétálva fel a lépcsőn -, és ahonnan gyakran szürődött ki az „özönvíz előtti” mechanikus írógépének zakatolása. Utoljára 2018 júniusában találkoztam vele otthonában. Kiss Jenőnek, a Magyar Nyelvtudományi Társaság elnökének megbízásából elvittem neki a Társaság történetéről szóló, Szathmári István által jegyzett könyvet, azzal a kéréssel, hogy röviden foglalná írásba emlékeit arról az időszakról, amikor ő tagja lett a Társaságnak. Nem hárította el a kérést, de fogyatkozó fizikai erejére való tekintettel időt kért erre. Mindannyiunk sajnálatára ez a visszaemlékezés végül is nem készült el.

Elekfi László az egyik leghosszabb életü, szellemi erejét az utolsó pillanatig megőrző magyar nyelvész volt. Gazdag és értékes tudományos életmüvet hagyományozott az utókorra, emberi jóságára pedig mindig emlékezni fogunk.

GERSTNER KÁROLY

MTA Nyelvtudományi Intézet

\title{
B. Gergely Piroska
}

(1932-2019)

2019 nyara szomorú hírt hozott a magyar nyelvésztársadalom számára: B. Gergely Piroska, az erdélyi és anyaországi magyar nyelv- és névtörténet kiváló kutatója és oktatója távozott közülünk. Bár én nem nevezhetem magam a szó szoros értelmében a tanítványának, máig is sokat idézett, alapmüként forgatott munkáinak köszönhetöen mégis sokat tanulhattam tőle, a magyar nyelv- és névtörténészek számos nemzedékével együtt. Tudományos pályájának mérlege 5 önálló kötet, több mint 70 tanulmány és közel 30 recenzió és megemlékezés, ami már önmagában is tiszteletre méltó tudományos teljesítményt tükröz. A sivár számok azonban még a kutatói életmü teljességéről se tanúskodnak méltóképpen, s végképp nem tárhatják elénk a tudós tanár, a szótárszerkesztő és a tudományszervező alakját. Annál többet tudhatunk meg róla az azóta szintén nyelvésszé vált tanítványai és kollégái visszaemlékezéseiből, történeteiből: ezekből egy szigorú, de hallgatói iránt elkötelezett oktató, egy fiatalabb kollégáit lényegre törő kérdésekkel, hasznos tanácsokkal és dicsérő szavakkal mindig biztatni kész patróna és a tanszékéért erőn felül küzdő vezető képe rajzolódik ki előttünk. A nyelvtudomány iránti elkötelezettségét mi sem bizonyítja jobban, mint az a tény, hogy kutatói és oktatói munkája mellett az érdeklődő nagyközönség tájékoztatásáról sem feledkezett meg: száznál is több ismeretterjesztő cikket írt romániai folyóiratokba és napilapokba. Pályájának alábbi áttekintésével most nemcsak a magam, hanem a Magyar Nyelvtudományi Társaság és a Magyar Nyelv nevében is igyekszem méltó módon búcsút venni az embertől, kutatótól és tanártól, aki hallgatók, köztük későbbi nyelvészek generációit vezette be a nyelvtörténet és a névtan világába.

B. Gergely Piroska tudományos pályája a kolozsvári egyetem magyar nyelv és irodalom szakán indult. Miután 1956-ban megszerezte diplomáját, tanársegéddé nevezték ki 
a Magyar Nyelvtudományi Tanszékre, és mestere, Szabó T. Attila mellett bekapcsolódott az itt végzett oktató- és kutatótevékenységekbe. Ezek közül a legkiemelkedőbb feladatot kétségkívül az Erdélyi magyar szótörténeti tár munkálatai jelentették; amellett, hogy a szerkesztőbizottság tagjaként évtizedekig részt vett e hatalmas vállalkozásban, számos tanulmányának forrásanyagát is belöle merítette. Munkájának elismeréseképpen 1970-ben adjunktussá, 1982-ben docenssé nevezték ki, 1985-1989 között pedig tanszékvezetőként is Szabó T. Attila nyomdokaiba lépett.

Ennek az első, erdélyi korszaknak a terméke volt 1974-es kandidátusi értekezése, mely 1977-ben A kalotaszegi magyar ragadványnevek rendszere címmel jelent meg, alapvetően meghatározva a későbbi ragadványnév-kutatások irányait, szempontjait és módszereit. A kalotaszegi személynévanyag feldolgozását aztán a későbbiekben két újabb monográfiával tette teljessé: A kalotaszegi magyar családnevek rendszertani és funkcionális vizsgálata 1981-ben, a Kalotaszeg magyar kereszt- és becenevei pedig 2005-ben látott napvilágot. Ez utóbbi évszám is tanúskodik arról, hogy a kutató Erdélyt elhagyva sem lett hütlen szükebb pátriájához. Megmutatkozik ez azokban a munkáiban is, melyeket az erdélyi asszonyok történeti névformáinak, valamint az itteni vallási felekezetek középmagyar kori névhasználatának szentelt.

Az oktatói életút második szakasza a 90-es években, immár Magyarországon kezdődött. A Miskolci Egyetem hívásának eleget téve 1992-ben megalapította, majd vezette a Magyar Nyelvtudományi Tanszéket, munkájával és kitartásával nagymértékben hozzájárulva a Bölcsészettudományi Kar létrehozásához. A fiatal tanszék tudományos hírnevének megalapozását szolgálta az V. Magyar Névtudományi Konferencia (1995) miskolci megrendezése is, melyben - kötetének szerkesztésével együtt - vezető szerepet játszott.

Miskolc mellett a Debreceni Egyetemen is tanított a nyelvtudományi doktori iskola oktatójaként. Habilitációs előadását is itt tartotta 1998-ban. A következő évben Miskolcon egyetemi tanárrá nevezték ki, 2002-től pedig - 2013-as nyugdíjba vonulásáig - professor emeritusként vett részt tanszéke életében. Ezt követően sem szakadt el azonban a tudománytól: továbbra is szerepet vállalt a magyarországi és erdélyi fokozatszerző eljárások bizottságaiban, előadóként és hallgatóságként egyaránt állandó résztvevője volt a névtudományi konferenciáknak, és figyelmes szemmel követte a legfrissebben megjelenő szakirodalmat. Ennek bizonyítékaként még 2017-ben és 2018-ban is jelent meg könyvismertetése a Névtani Értesítőben.

2012-ben 80. születésnapját a saját tanulmányaiból összeválogatott gyüjteményes kiadvánnyal ünnepelték meg kollégái és tanítványai a Miskolci Egyetemen, tudományos életmüvének impozáns bibliográfiáját is közreadva. Munkásságát számos díjjal is elismerték: 1982-ben a Magyar Nyelvtudományi Társaság Csűry Bálint-díjjal, 1998-ban pedig Pais Dezső-díjjal tüntette ki, 2001-ben a Miskolci Egyetem Signum Aureum Universitas kitüntetést adományozott neki, 2009-ben pedig az Erdélyi magyar szótörténeti tár szerkesztőbizottságában végzett 40 évnyi munkájáért részesült gróf Mikó Imre-díjban.

Ezek az elismerések is jól tükrözik azt a megbecsülést, amellyel barátai, kollégái és tanítványai adóznak B. Gergely Piroska kutatói és oktatói munkásságának. Bár tanácsait, elgondolkodtató kérdéseit és támogató szavait már örökre nélkülöznünk kell, teljes és gazdag életmüve velünk marad, még hosszú ideig alapvető hivatkozási alapul szolgálva a nyelvtörténeti és névtudományi kutatások számára. 